ISSN 2073-4441

www.mdpi.com/journal/water

Article

\title{
Smart Metering and Water End-Use Data: Conservation Benefits and Privacy Risks
}

\author{
Damien P. Giurco $^{1, *}$, Stuart B. White ${ }^{1}$ and Rodney A. Stewart ${ }^{2}$
}

1 Institute for Sustainable Futures, University of Technology, Sydney, P.O. Box 123 Broadway, New South Wales 2007, Australia; E-Mail: Stuart.White@uts.edu.au

2 Centre for Infrastructure Engineering and Management, Griffith University, Gold Coast, PMB 50 Gold Coast Mail Centre, Queensland 9726, Australia; E-Mail: R.Stewart@griffith.edu.au

* Author to whom correspondence should be addressed; E-Mail: Damien.Giurco@uts.edu.au; Tel.: +61-2-9514-4978; Fax: +61-2-9514-4941.

Received: 2 August 2010 / Accepted: 17 August 2010/ Published: 19 August 2010

\begin{abstract}
Smart metering technology for residential buildings is being trialed and rolled out by water utilities to assist with improved urban water management in a future affected by climate change. The technology can provide near real-time monitoring of where water is used in the home, disaggregated by end-use (shower, toilet, clothes washing, garden irrigation, etc.). This paper explores questions regarding the degree of information detail required to assist utilities in targeting demand management programs and informing customers of their usage patterns, whilst ensuring privacy concerns of residents are upheld.
\end{abstract}

Keywords: urban water; end use measurement; water efficiency

\section{Introduction}

Australian cities, like many around the world, are facing challenges of meeting supply-demand balance for urban water as populations rise and climatic change alters the yield from rain-fed supply systems such as dams [1]. In response, supply augmentation infrastructure such as desalination plants have been built as well as pursuing water efficiency initiatives in industry and households [2]. Smart metering too, has an important role to play in demand management from the utility perspective and also providing information to inform behavior change from the customer perspective. Stewart et al. [3] highlight that "the advent of advanced water metering, logging and wireless communication 
technologies has enabled the dynamic accurate measurement and data transfer of useful end-use water consumption information (e.g., time and quantity of water use in a shower)”.

However, what remains to be explored is how this data can be effectively managed to fulfill its potential benefits and at the same time what questions need to be asked and answered to ensure privacy issues do not derail the wider implementation of the technology. Currently, such issues are dormant in many communities in Australia due to severe water shortages from drought, which have led to an attitude of "let's do whatever it takes" to conserve water as it is such a precious resource.

This paper begins by outlining the potential role for smart metering and end use information for integrated resources planning in urban water. It then maps the potential benefits and risks associated with how differing levels of information detail are used and communicated. Finally, the paper concludes with a summary of the key issues to be addressed in future research.

\section{Role of Smart Metering and Water End-Use Data for Integrated Resources Planning}

We begin by exploring the information needs of integrated resources planning and identifying the role which water end-use data supplied by smart metering can play.

The Australian Framework for Integrated Resources Planning (IRP) is shown in Figure 1 with important contributions of smart metering and end-use data circled. The framework follows a cycle of planning, analysis, developing and implementing a response to achieve supply-demand balance and then monitoring and evaluation [4]. It has also been linked to deliberative processes to assist with planning under uncertainty [5]. The key attributes of such data are that they are more accurately resolved in terms of end-use and are available in near-real time, allowing the detection of behaviors which are more difficult to identify through meter readings occurring a few times per year. The advantages are shown in Table 1.

Table 1. Benefits of end-use data supplied by smart metering at each stage of Integrated Resources Planning (IRP).

\begin{tabular}{|c|c|c|}
\hline IRP Stage & Benefit of end-use resolution & Benefit of near real-time data \\
\hline 1. Plan the process & - Better historical context of use & $\begin{array}{l}\text { Ability to identify daily, } \\
\text { weekly, seasonal patterns }\end{array}$ \\
\hline 2. Analyze the situation & $\begin{array}{l}\text { - More accurate end-use based } \\
\text { demand forecast }\end{array}$ & $\begin{array}{l}\text { - Real-time data less helpful at } \\
\text { this stage }\end{array}$ \\
\hline 3. Develop the response & $\begin{array}{l}\text { - Ability to target demand } \\
\text { management options based on } \\
\text { end-uses and conservation } \\
\text { potential }\end{array}$ & $\begin{array}{l}\text { - Understanding of use patterns } \\
\text { can help identify conservation } \\
\text { potential and appropriate } \\
\text { instrument for implementing } \\
\text { conservation measures }\end{array}$ \\
\hline 4. Implement the response & $\begin{array}{l}\text { - Ability to provide greater } \\
\text { resolution of information detail to } \\
\text { customers during implementation }\end{array}$ & $\begin{array}{l}\text { Ability to provide timely } \\
\text { information to customers } \\
\text { during implementation }\end{array}$ \\
\hline 5. Monitor, evaluate and review & $\begin{array}{l}\text { - Ability to get detailed insights } \\
\text { into success of program based on } \\
\text { changes to end-use demand }\end{array}$ & - Ability to monitor in real-time \\
\hline
\end{tabular}


Figure 1. Integrated Resources Planning (IRP) process with contribution of smart metering and end-used based data highlighted (after [4]).

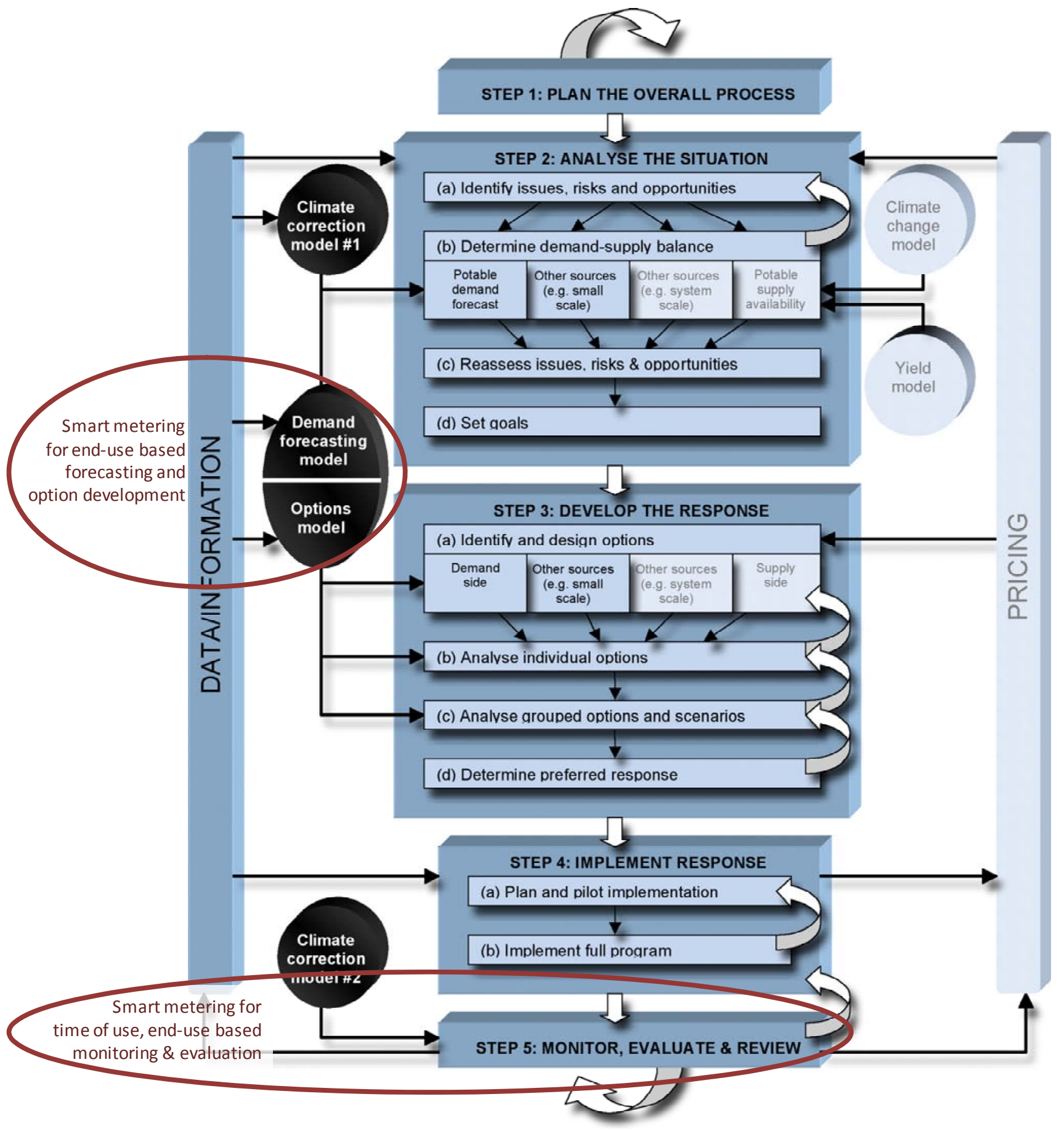

An example of the water end-use breakdown which can be provided by smart metering in liters/person/day (L/p/d) and percent (\%) for a Gold Coast, Australia sample is shown in Figure 2. This figure is an aggregated representation of two weeks of collected data, however, underlying this summary is a database containing time of use data for individual water using events. 
Figure 2. End use breakdown, Gold Coast (winter pre-retro fit) [6].

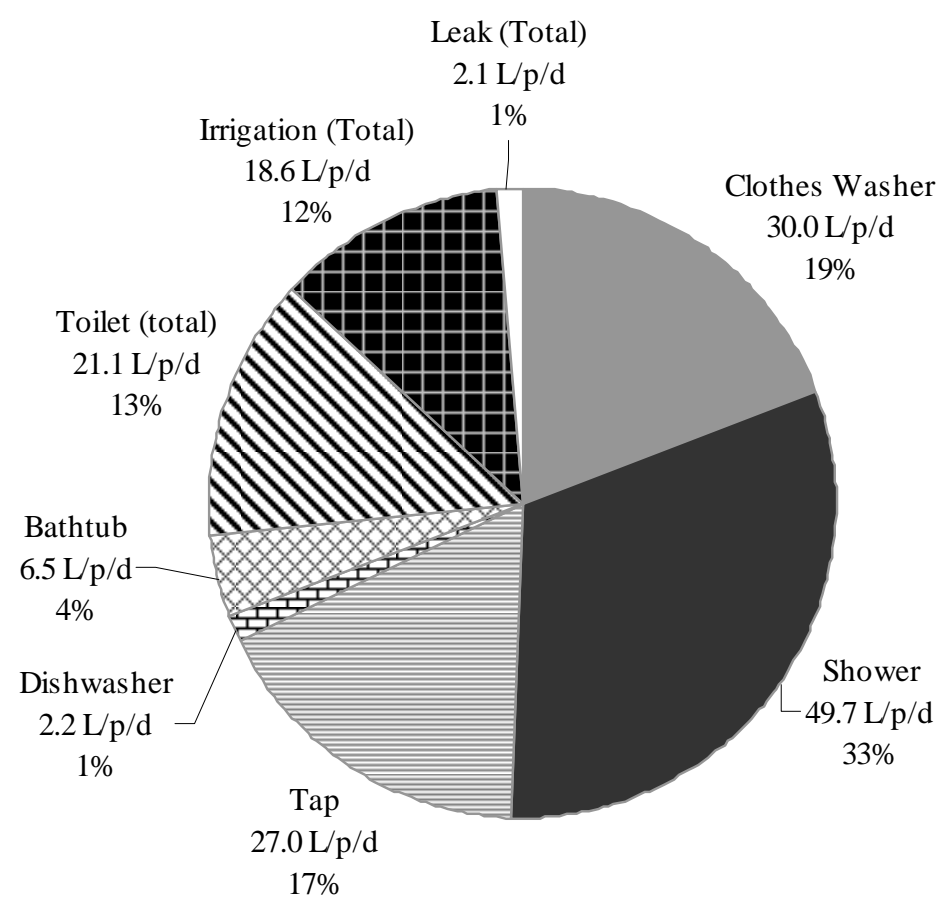

Smart metering technology has enabled an increase in the availability and detail of consumption data for utilities [7]. Greater technological capability allows higher order objectives to be met as shown in Figure 3. However, the development of automated processes to transfer the large volumes of data into information that can be used for decision making by utilities or householders requires further development, both in terms of hardware and software performance as well as the utility's business systems to integrate and use the data effectively, such as to implement time of use pricing.

Figure 3. Aligning smart metering technology capability with utility objectives [8].

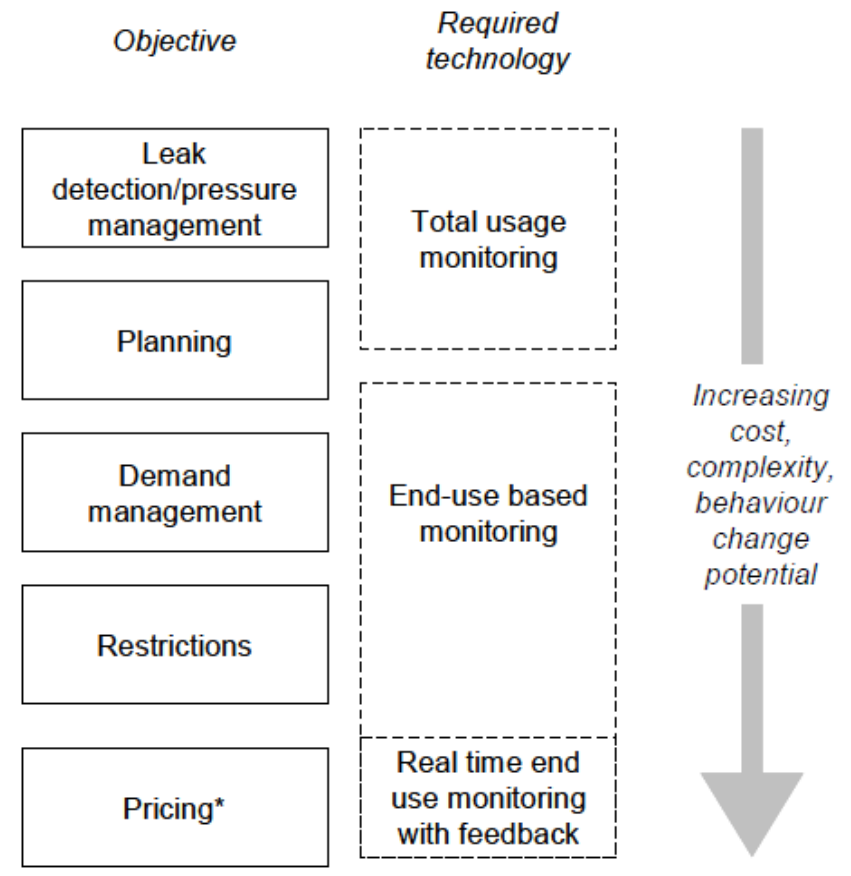


The appropriate interface for communicating this information transfer must also be researched. Shackel [9] argues that "much basic work is needed, both empirical and theoretical, to develop our scientific understanding of the characteristics and performance of humans as IT users". In the Australian urban water context, there is mixed success of education-based water saving initiatives [10], which can be linked to the lack of individual consumption data for households. Moreover, there are many factors influencing water use that are not included in assessments of factors influencing householder behavior (often due to the difficulty in quantifying or obtaining information on these factors [11]).

A more thorough approach would also bring theory from the decision sciences [12-14] to studying behavior change in the urban water context, specifically, to identify the form of information which is most useful for decision making by household consumers and the water utility. Whilst initial research on how the level of information detail from smart metering affects electricity consumption has been completed [15,16], further work is needed to gain a detailed understanding of how this knowledge of resource use affects water use behaviors in the water context. This understanding also affects water planners from government and utilities, as knowledge of customer behaviors has an impact on the design of effective water saving and education programs.

Increasing information collection offers potential to target customers to reduce water use through behavior change as part of IRP for urban water. The IRP framework is recognized internationally as a best practice theoretical framework used in the planning of urban water resources [4]. Understanding the role of information and the household consumer is integral for transforming a "Water Supply City" where the focus is on infrastructure alone to a "Water Sensitive City" where infrastructure, users and the environment are integrated [17]. Such information will also be useful for smarter responses to climate change in cities through the use of an integrated assessment platform modeling water, energy and transport use [18]. However, householders may not use information that they are given, unless they can understand it in their own context and interpret what that information might mean to their daily life. Whilst smart metering technologies have the capability to provide information on both water use and behavior change over time, the collection of increased information comes with increased privacy risks [19].

\section{Reconciling Potential Conservation Benefits and Privacy Risks}

Developing a context-specific theoretical framework for determining how householder privacy is impacted by collection and communication of detailed water-use information is essential if smart meters are to revolutionize planning and adaptive management of urban water resources in response to future uncertainty from climate change.

The potential conservation benefits include reductions of up to $20 \%$ in water demand and reduced sewage discharge and reduced energy usage, both from pumping and treatment, but also within households (e.g., in showers arising from greater information on usage patterns being given to residents). There are also avoided monetary and environmental costs associated with the construction and use of redundant urban infrastructure due to effective demand management strategies being informed by the smart metering technology within an IRP framework. This translates to the maintenance of biodiversity and ecosystem function, as well as reductions in green house gas emissions. 
There are potential social benefits including more informed community sector usage patterns, establishment of an evidence base for education/change policies, establishment of long-term water conservation practices, and collaborative community development of water saving initiatives. However, there is also potential privacy concerns associated with who has access to what level of detail of information. Who is allowed to see when the house is not using water (showing it is vacant); or when it is using water in excess of that allowed under mandatory restrictions (will customers be happy big brother is watching); could it lead to establishing competitions between householders, streets or suburbs through social networking sites (is this a good thing to promote water saving, such as the voluntary scheme Climate Clubs-would marketers then have access to this data and target advertising relating to gardening enthusiasts or those suffering incontinence) or if such trends are reported more widely will it stigmatize cultural groups or locations for unusual water using practices which are not the norm?

\section{Conclusion}

This paper has highlighted three aspects associated with the introduction of smart metering technology which require further consideration-potential conservation benefits for consumers and utilities, the potential for streamlined business management and pricing based on time of use, contrasted with the real risk of consumer privacy breaches which requires further input and discussion from all stakeholders. The more extensive roll out of electricity smart meters (e.g., in Victoria, Australia), which were aimed at improving efficiency and reducing consumption and greenhouse gas emissions, but which had unexpected opposition due to changes in charges for lower socio-economic groups [20], also highlights the need to include social factors into any technology futures assessment as is happening in other industry sectors (see for example [21]).

\section{References}

1. Fane, S.A.; Patterson, J.J. Urban water planning in the face of climate change. Water:J. Aust. Water Assoc. 2009, 36, 84-89.

2. Giurco, D.; Bossilkov, A.; Patterson, J.; Kazaglis, A. Developing industrial water reuse synergies in Port Melbourne: Cost-effectiveness, barriers and opportunities. J.Clean. Prod. 2010, doi:10.1016/j.jclepro.2010.07.001.

3. Stewart, R.A.; Willis, R.; Giurco, D.; Panuwatwanich, K.; Capati, G. Web-based knowledge management system: linking smart metering to the future of urban water planning. Aust. Plan. 2010, 47, 66-74.

4. Turner, A.; Willets, J.; Fane, S.; Giurco, D.; Kazaglis, A.; White, S. Guide to Demand Management;Water Services Association of Australia: Sydney, Australia, 2008.

5. White, S.; Fane, S.; Giurco, D.; Turner, A. Putting the economics in its place: decision making in an uncertain environment. In Deliberative Ecological Economics; Zografos, C., Howarth, R., Eds.; Oxford University Press: New Dehli, India, 2006; pp. 80-106.

6. Willis, R.; Stewart, R.; Panuwatwanich, K.; Capati, B.; Giurco, D. Gold Coast domestic water end use study. Water: J. Aust. Water Assoc. 2009, 36, 91-97. 
7. Neenan, B.; Hemphill, R.C. Societal Benefits of Smart Metering Investments. Electricity J. 2008, 21, 32-45.

8. Giurco, D.; Carrard, N.; Inman, M. Water End-Use Measurement: A Guide to Study Design, Sampling and Smart Metering Technology; Verlag Dr Muller: Saarbrücken, Germany, 2009.

9. Shackel, B. Human-computer interaction-Whence and whither? Interact. Comput. 2009, 21, 353-366.

10. Syme, G.; Nancarrow, B.; Seligman, C. The evaluation of information campaigns to promote voluntary household water conservation. Evaluation Rev. 2000, 24, 539.

11. Jorgensen, B.; Graymore, M.; O'Toole, K. Household water use behavior: An integrated model. J. Environ. Manage. 2009, 91, 227-236.

12. Ajzen, I. The theory of planned behavior. Organ. Behav. Hum. Decision Proc. 1991, 50, 179-211.

13. McKenzie-Mohr, D.; Smith, W. Fostering Sustainable Behavior: An Introduction to CommunityBased Social Marketing; New Society Publishers: Gabriola Island, BC, Canada 1999.

14. Keeney, R.; Raiffa, H. Decisions with Multiple Objectives: Preferences and Value Tradeoffs; Cambridge University Press: Cambridge, UK, 1993.

15. Abrahamse, W.; Steg, L.; Vlek, C.; Rothengatter, T. The effect of tailored information, goal setting, and tailored feedback on household energy use, energy-related behaviors, and behavioral antecedents. J. Environ. Psychol. 2007, 27, 265-276.

16. Fischer, C. Feedback on household electricity consumption: a tool for saving energy? Energ. Efficiency 2008, 1, 79-104.

17. Brown, R.; Keath, N.; Wong, T. Urban water management in cities: historical, current and future regimes. Water Sci. Technol. 2009, 59, 847-855.

18. Boydell, S.; Giurco, D.; Rickwood, P.; Glazebrook, G.; Zeibots, M.; White, S. Using an integrated assessment model for urban development to respond to climate change in cities. In Energy Efficient Cities: Assessment Tools and Benchmarking Practices; Bose, R., Ed.; The World Bank: Washington, DC, USA, 2010; pp. 65-91.

19. McIntyre, T.J. Data retention in Ireland: Privacy, policy and proportionality. Comput. Law Secur. Rep. 2008, 24, 326-334.

20. Collins, S.-J. Power Bill Pain as Smart Meter Cost Blows Out. The Age 19 May 2010.

21. Franks, D.; Cohen, T.; McLellan, B.; Brereton, D. Technology Futures Discussion Paper: Technology Assessment and the CSIRO Minerals Downunder National Research Flagship. Cluster Reasearch Report No. 2.1; Centre for Social Responsibility in Mining Sustainable Minerals Institute, The University of Queensland: Brisbane, Australia, 2010.

(C) 2010 by the authors; licensee MDPI, Basel, Switzerland. This article is an Open Access article distributed under the terms and conditions of the Creative Commons Attribution license (http://creativecommons.org/licenses/by/3.0/). 